専門医症例報告

前歯部の咬合接触の改善により新義歯の咬合高径に順応した無歯顎症例 坪井 明人

\title{
An Edentulous Patient Adapting a New Complete Denture with Increased Occlusal Vertical Dimension due to Improved Anterior Teeth Contacts
}

\section{Akito Tsuboi}

\begin{abstract}
抄 録
症例の概要：患者は，義歯床下粘膜の疼痛および咀嚼障害を主訴とした 80 歳男性である，新製した総義 歯の装着により主訴は改善されたが，患者は過高感を訴えた。適切に回復されたと考えられた咬合高径は 変えず，下顎偏心運動の極初期から上下顎前歯部が咬合接触する義歯を再製作した．新義菌装着直後より 過高感は消退した。 4 年 6 カ月間，この咬合高径が維持され，経過も良好である。 考察：総義歯装着者の咬合高径の受容においては, 咀嚼筋や顎関節からの感覚情報とともに, 義歯床下粘 膜からの情報も関与することが示唆された。

結論：総義歯を十分に機能させるには，前歯部の咬合接触の強さ，タイミングなどをも考慮した咬合の付 与が肝要である.
\end{abstract}

和文キーワード

無歯顎，咬合高径，前歯部，咬合接触，口腔粘膜

\section{ABSTRACT}

Patient: An 80-year-old male patient with maxillary and mandibular complete dentures visited our hospital with the chief complaint for pain of oral mucosa under the dentures and difficulty of chewing. New dentures were fabricated and inserted to treat the poor denture-tissue relation and inadequate mandibular position. The patient detected higher occlusal vertical dimension (OVD), although the OVD could be appropriately reestablished by mechanical and physiologic methods. The sensation of higher OVD was diminished after insertion of an improved maxillary denture with anterior artificial teeth contact to opposing ones at the onset of the mandibular eccentric movement. This OVD has been maintained with a good prognosis for 4.5 years.

Discussion: This case suggested that denture wearer's acceptance of OVD is influenced by sensory information from oral mucosa as well as masticatory muscles and temporomandibular joint.

Conclusion: An occlusion with adequate anterior teeth contacts allows performing the sufficient function of complete denture.

\section{Key words}

edentulous, occlusal vertical dimension, anterior teeth, occlusal contact, oral mucosa 


\section{I 。緒言}

咬合高径が低下した状態で長期間経過した症例に，適 切な咬合高径を設定することは容易ではない。一方，咬 合高径の低下は，下顎の前方偏位を誘導するため，この ような症例では，前歯部の咬合接触やガイドが，静的お よび動的顎間関係と不調和をきたしていることがしば しば観察される。

本症例報告では，顔貌や頭部 X 線規格写真の計測か ら適切と考えられる咬合高径か設定されたものの，これ を「高い」と自覚する症例に対して，下顎の偏心運動の 極初期から咬合接触が得られるように修正した義歯を 装着し，前歯部の咬合接触の強さとその夕イミングを改 善することにより，この咬合高径に対するすみやかな順 応が得られ，その後 4 年半にわたり良好な経過を示し た症例を報告する。

\section{II . 症例の概要}

患者：80 歳 4 力月（当科初診時）, 男性

初診 : 2002 年 7 月 19 日

主訴：下顎義歯床下粘膜の疼痛および咀嚼障害

現病歴：40 歳頃には, 残存歯が下䫈前歯部のみとな り，70 歳頃に無歯顎になったという。2001 年 7 月に, 現在使用している義歯（旧義歯）を近医（歯科）にて 製作した，頻回の義歯調整を受けたものの，満足でき る適合が得られず，咀嚼障害も改善されなかったため， 2002 年 7 月，当科を受診した。

現症：旧義歯装着時の顔貌は，オトガイ部が突出し， 口唇は緊張が弱くて薄い。 口角部も緊張がなく下降して いた。

口腔内所見：上下顎無歯顎である。上顎前歯部顎堤 は，ロール状を呈し被圧縮性は大きい。両側臼歯部には 骨隆起が認められた。回蓋粘膜の被圧縮性は大きくない。

下顎前歯部顎堤には，十分な骨量があった。しかし， 被覆粘膜は菲薄であり，粘膜下の骨面に数個の凹凸が触 知された。また，臼歯部顎堤は平坦であり，顎堤粘膜の 被圧縮性は小さかった（図 1).

義歯所見：義歯床の大きさには，あまり問題はなかつ たが，義歯床粘膜面と義歯床下粘膜とに著しい不適合が 認められた。一方，過度の咬合調整による咬頭の喪失の ため，人工歯の咬合面は平坦になっていた（図 2)。旧 義歯を装着して咬合させると, 左側臼歯部の咬合が弱く, 中心咬合位は不安定であった。また，習慣性の中心咬合 位は，頭位を直立させ，きわめて軽いタッピング運動を
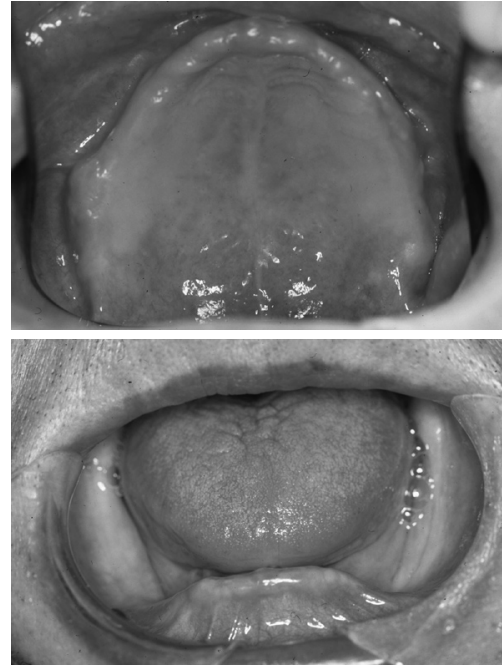

図 1 Intraoral views at the first examination 初診時口腔内
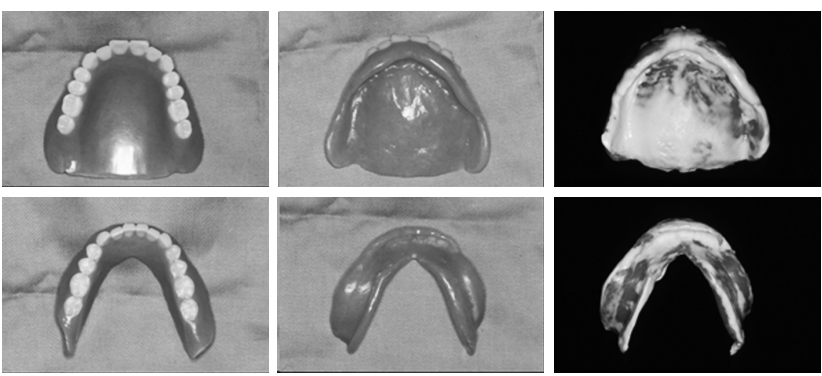

図 2 Dentures at the first examination 旧義歯
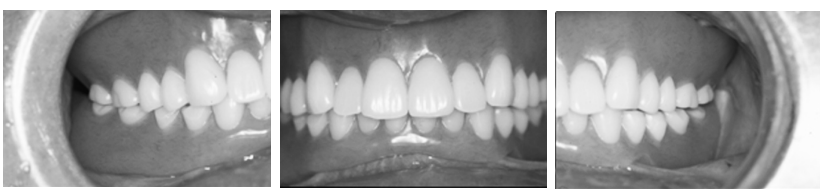

図 3 Insertion of dentures at the first examination 旧義歯装着時の口腔内

行わせて咬合接触が得られた時の下顎位である生理的 中心位 ${ }^{1)} よ り も$ 前方にあった。一方，過大なオーバー バイトによる義歯の動摇が観察された（図 3 ).

機能所見 : 開口障害，顎関節雑音，顎関節および咀嚼 筋群の圧痛や運動痛は認められなかった。

診断と治療方針：以上より，(1)義歯不適合および咬合 の異常によって惹起された義歯床下組織の疼痛および 咀嚼障害，(2)咬合高径の減少と診断した。そこで，治療 方針は，適切な垂直的，水平的下顎位の設定の後，新た に上下顎総義歯を製作することとした。 


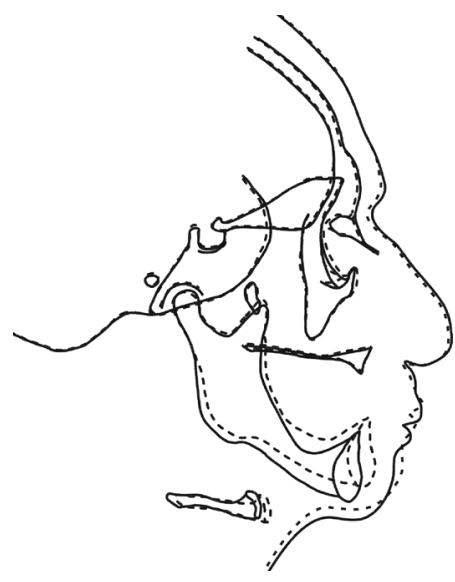

図 4 Cephalometric analysis

Broken line: with dentures at the first examination, solid line: with new complete dentures

セファロ分析

点線：旧義歯装着時, 実線 $:$ 新義歯装着時

\section{III．治療内容と経過}

治療内容: 研究用模型を製作後, 個人トレーとモデリ ングコンパウンド，イソコンパウンドにて筋圧形成を行 い，チオコールラバー印象材を用いて精密印象を採得し た。顎間関係は，咬合床を用いて記録した。その際，咬 合高径は，下顎安静位法および顔貌所見から設定し，水 平的中心咬合位は，反復咬合法および苝下運動利用法を 用いて設定した。鼻下点一オトガイ底間距離を計測して 得られた咬合高径は, 旧義歯装着時のものに比較して $7 \mathrm{~mm}$ 増加した。また，頭部 X 線規格写真を用いた計測 によっても，新義歯装着時の ANS-Menton は，旧義歯 装着時よりも $7 \mathrm{~mm}$ 増加していた（図 4 ）。前歯部人工 歯は，自然観の回復を重視して選択および排列した。臼 歯部人工歯排列では，フルバランスド・オクルージョン を付与した。蝻義歯試適から装着に至る過程は, 通法に 則って行った（図 5,6 ).

義歯の適合および維持，安定は十分に得られ，義歯床 下粘膜の疼痛は消失し, 咀嚼障害も軽減した。しかし, 新義歯装着後 4 週間, 患者は数度の咬合調整後も過高 感を訴えた。顔面計測（Willis 法）および頭部 X線規格 写真における計測值は一般的な值であった。一方，口腔 内診査の結果，前歯部の咬合接触が弱いことが認められ た。そこで，上下顎義歯の前歯部のオーバーバイトなら びにオーバージェットを減少させ，下顎の偏心運動の極 初期から咬合接触するように前歯部人工歯排列のみを
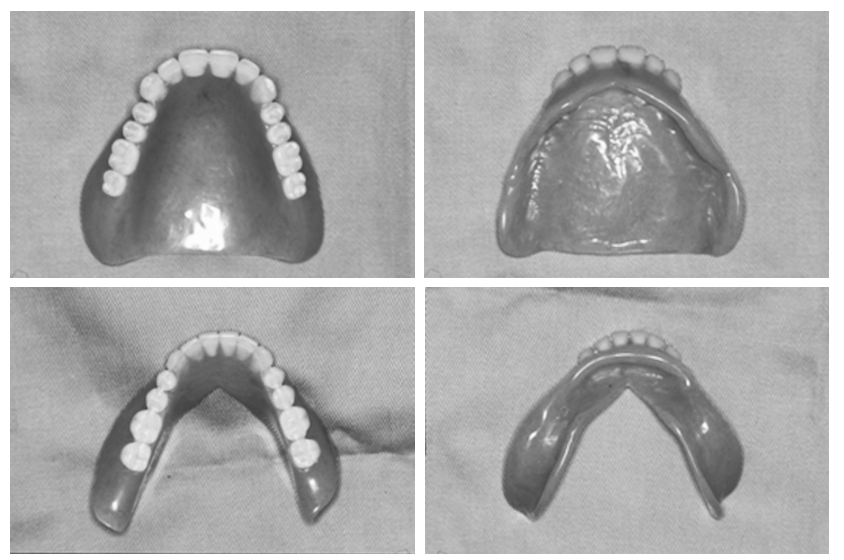

図 5 New maxillary and mandibular complete dentures 新義歯

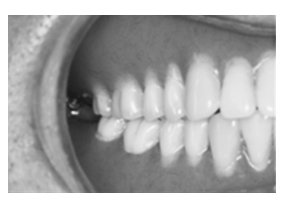

図 6
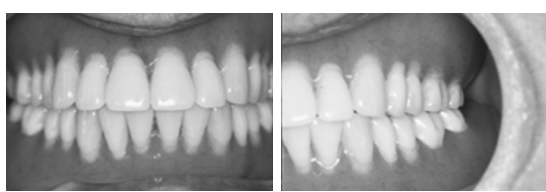

Insertion of new dentures 新義歯装着時の口腔内
変えた上顎義歯のみを再製作した（図 7 ）。

経過：改良した上顎義歯（改良義歯）装着直後より咬 合の過高感は消退した。平成 19 年 4 月に義歯破損によ り下顎義歯のみ再製作したが, 現在まで (4 年 6 力月間) この咬合高径がほぼ維持されている（図 8 )。また，義 歯装着後の経過観察中に, 顎関節や咀嚼筋群の症状は認 められず，咬合も安定しており，良好な経過を得ている。

\section{IV. 考 察}

咬合高径が低下した状態で長期間経過した症例では, 旧義歯を利用した治療義歯などを用いて，現在の咬合高 径から適切と考えられる咬合高径まで, 試行錯誤を繰り 返しながら，咬合挙上する手法が一般に用いられている 2).しかし，この手法は患者の主観的感覚が重視される ために, 習慣性の中心咬合位での咬合採得が行われ易く, ほとんど咬合挙上されていない症例をしばしば認める。

本症例では，治療義歯等は用いず，咬合採得時に下顎 安静位法および顔貌所見から咬合高径を設定した。その 結果，新義歯装着時の咬合高径は，旧義歯装着時に比較 して $7 \mathrm{~mm}$ 増加し，頭部 X 線規格写真上で咬合高径の 指標となる下顔面高 (ANS-Menton) は, 69mm となっ た. 日本人無歯顎高齢者の ANS-Menton の平均値は, $68.9 \mathrm{~mm}\left(\mathrm{n}=41\right.$, 内田 $\left.{ }^{3)}\right), 70.7 \pm 6.3 \mathrm{~mm}(\mathrm{n}=60$, 虫 


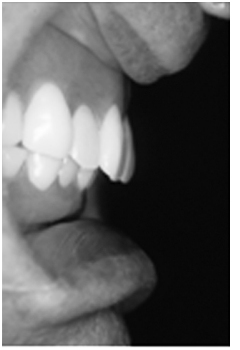

a

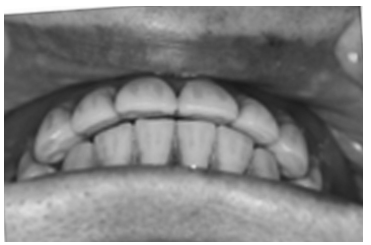

d

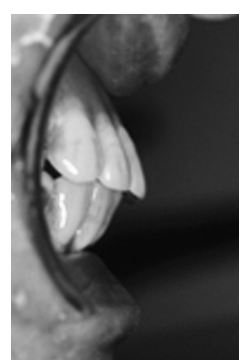

b

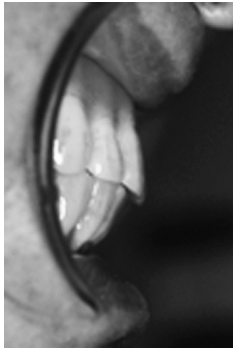

C

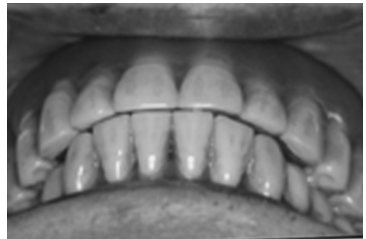

e
図 7 Lateral views of anterior teeth contacts $a$ : at the first examination, $b, d$ : at the insertion of new dentures, c, e: at the insertion of improved maxillary denture 前歯部側面観

$\mathrm{a}$ : 旧義歯，b，d：新義歯， $\mathrm{c} ， \mathrm{e}$ : 改良上枵義歯

本 $\left.{ }^{4)}\right)$ であり，新義歯装着時の咬合高径は，これらの 值と近似していた。 さらに，Willis の顔面計測法によれ ば，適切な咬合高径では鼻下点 - オトガイ底間距離 /瞳 孔 - 口裂間距離はほぼ 1.0 になるとされており，本症例 では旧義歯装着時 0.9 , 新義歯装着時 1.0 であったこと から, 本症例で求めた咬合高径が啇正であったことが推 察された。

以上のように，適切と考えられる咬合高径を設定した にもかかわらず，患者は咬合高径の過高感を訴えた。こ の結果は，筋紡錘，顎関節機械受容器および臼歯部の咬 合接触によって得られる咬合感覚と前歯部の咬合接触 から得られる咬合感覚との不調和により生じたものと 考えられた。そこで，咬合高径は変化させずに，前歯部 のオーバージェットおよびオーバーバイトを減少させ, 下顎の偏心運動の極初期から咬合接触が得られるよう に修正した義歯を装着した。装着直後より過高感は消失 し，経過観察期間を通して，付与された咬合による顎口 腔機能の不具合は認められなかった。

咬合高径は，主に閉口筋中の筋紡錘あるいは顎関節機 械受容器からの感覚情報により知覚される ${ }^{5,6)}$. 本症例 の経過は，この咬合高径の知覚機序に，咬合接触を介し た口腔粘膜からの情報も関与することを示唆している. したがって，前歯部の咬合接触の強さ，タイミングなど をも考慮した咬合の付与が，総義歯の機能を十分に発揮 させるためには肝要であると考えられた。

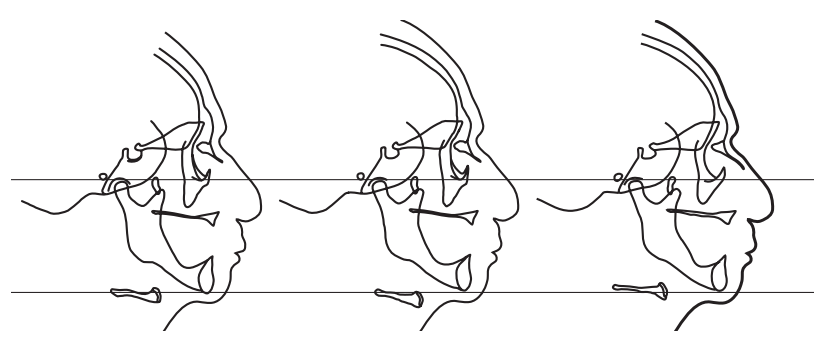

図 8 Cephalometric analysis

left: at the insertion of new denture, middle: at the insertion of improved maxillary denture, right: 4 years after セファロ分析

左：新義歯装着時, 中央：改良義歯装着時，右： 改良上顎義歯装着 4 年後

\section{V. 結 論}

咬合高径の知覚には，前歯部での咬合接触感覚が関与 していることが示唆された。したがって, 総義歯の機能 を十分に発揮させるためには, 前歯部の咬合接触の強さ, タイミングなどをも考慮した咬合の付与が肝要である と考えられる。

\section{文献}

1）渡辺 誠。バイオフィードバックを応用した榕合診査. 全身咬合 2003; 9: 81-85.

2） 中尾勝彦。パイロットとしての治療用義歯. 日歯会誌 1994; 46: 1050-1058.

3）打田年実. 頭蓋X線規格写真計測法による咬合高径の 研究. 口病誌 1978; 45: 669-681.

4）虫本栄子，田中久敏，井上大一ほか。総義歯患者の術 前術後に扮ける顎顔面形態の変化と咀嚼筋パターン. 補綴誌 1997; 41: 302-311.

5) Brill N, Tryde G. Physiology of mandibular positions. Front Oral Physiol 1974; 1: 199-237.

6) Zhang $\mathrm{W}$, Kobayashi M, Moritani $\mathrm{M}$ et al. An involvement of trigeminal mesencephalic neurons in regulation of occlusal vertical dimension in the guinea pig. J Dent Res 2003; 82: 565-569.

著者連絡先：坪井 明人 干 980-8575 宮城県仙台市青葉区星陵町 4-1 TEL : 022-717-8396

FAX : 022-717-8399

E-mail : tsuboi@mail.tains.tohoku.ac.jp 